\title{
Ecotoxicology assay for the evaluation of environmental water quality in a tropical urban estuary
}

\author{
JEAMYLLE NILIN ${ }^{1,2}$, ANDERSON A.O. SANTOS ${ }^{1}$ and MEGGIE K.S. NASCIMENTO ${ }^{2}$ \\ ${ }^{1}$ Departamento de Ecologia, Universidade Federal de Sergipe/UFS, Av. Marechal \\ Rondon, s/n, 49100-000 São Cristóvão, SE, Brazil \\ ${ }^{2}$ Programa de Pós-Graduação em Ecologia e Conservação, Universidade Federal de Sergipe/ \\ UFS, Av. Marechal Rondon, s/n, 49100-000 São Cristóvão, SE, Brazil \\ Manuscript received on March 5, 2018; accepted for publication on April 30, 2018
}

\begin{abstract}
How to cite: NILIN J, SANTOS AAO AND NASCIMENTO MKS. 2019. Ecotoxicology assay for the evaluation of environmental water quality in a tropical urban estuary. An Acad Bras Cienc 91: e20180232. DOI 10.1590/00013765201820180232 .
\end{abstract}

\begin{abstract}
Most studies evaluating the impacts of river pollution in the semi-arid region of Brazil have been geared towards physiochemical analyses, and investigations of the adverse effects of water pollution on associated organisms are scarce. This study aimed to evaluate the water quality in the Poxim river estuary in Aracaju, Sergipe throughout the dry and rainy season by evaluating the survival of the microcrustacean Mysidopsis juniae and physicochemical analyses. The evaluation of physiochemical parameters revealed a decrease in dissolved oxygen content in the rainy season. However, there was a significant reduction in microcrustacean survival in samples during the dry season, when the river flow is reduced and effluents become concentrated. These results suggest that pollutants received and carried by the waters of the Poxim River contribute to the reduction of environmental quality in the estuary, and this impact may vary according to dry and rainy patterns, that are uncertain considering the impacts of climate change on tropical regions.
\end{abstract}

Key words: Poxim River, Sergipe, Mysidopsis juniae, basic sanitation, acute toxicity, brackishwater pollution.

\section{INTRODUCTION}

Estuaries are transition zones between the continental and marine aquatic environments, and are fundamental for maintaining ecological processes in adjacent ecosystems. Tropical estuaries are threatened by the development of shrimp aquaculture (Hatje et al. 2016, SuárezAbelenda et al. 2014), deforestation of mangroves

Correspondence to: Jeamylle Nilin

E-mail: jeamylle@gmail.com

ORCid: http://orcid.org/0000-0002-1636-4541 and adjacent forests for aquaculture, real estate construction (Ferreira and Lacerda 2016, Nguyen et al. 2013), and input of industrial and domestic effluents (Maciel et al. 2015).

Eight of the nine state capitals in northeastern Brazil are located in the coastal zone, contributing significantly to the degradation of estuarine environments. Sergipe, the smallest Brazilian state, has six drainage basins that flow to a $163-\mathrm{km}$ area of coastline, forming estuaries and mangroves. The capital of Aracaju is delimited by two of these basins, the Vaza-Barris River in the south 
and the Sergipe River in the north; the area is also permeated by the Poxim River, which is a tributary of the Sergipe River. In addition to ecological value, the Poxim River has fundamental socioeconomic importance through supplying approximately $30 \%$ of the drinking water for inhabitants in the state capital city; this proportion has reached up to $70 \%$ in the past (Silva et al. 2004).

The Poxim River estuary lies completely within the urban area of Aracaju, passing through several neighbourhoods with ongoing real estate expansion. This further stresses water resources, particularly via the discharge of domestic effluents and surface runoff (Silva et al. 2004). Studies of the environmental quality of this important river have so far been limited to the evaluation of abiotic variables in the freshwater portion (Britto et al. 2012, De Aguiar Netto et al. 2013, Vasco et al. 2011). Although some of these studies indicate that the greatest degree of contamination occurs near the capital, studies of the estuarine region are still scarce (Araújo et al. 2008, Souza et al. 2018). The National Policy on Water Resources (Brasil 1997) oversees the integration of river basin management with estuarine systems and coastal zones; however, in practice, studies for basin management are often restricted to waters used for human consumption and watering livestock.

The degradation of surface and groundwater quality in Brazil is mainly linked to poor sanitation, especially in the urban centers. Studies evaluating water quality have often been based on physiochemical and microbiological parameters and have often ignored the possible biological effects on resident biota. Brazilian legislation was introduced in 2005 to include ecotoxicological tests for classification of water bodies, in addition to the evaluation of effluents in fresh, saline, and brackish waters (CONAMA 2005). However, ecotoxicological studies in Brazil still face major challenges regarding the standardization of protocols, the use of native species, the development of assays with different groups of the local rich biodiversity, and the lack of studies in representative aquatic environments, particularly in the northeast (Martins and Bianchini 2011).

Ecotoxicological studies in marine and estuarine environments in Brazil are commonly carried out using Mysidopsis juniae (Crustacea: Mysidae, Silva 1979) that is the only protocol standardized by the Brazilian Association of Technical Standards (ABNT) for the evaluation of acute toxicity (ABNT 2011). Mysids have been used for more than three decades in toxicity bioassays, because they are considered one of the most sensitive groups in the marine community and occupy the bottom level of the trophic chain (OECD 2006).

So, environmental quality in this area should be assessed through the measurement of physiochemical and ecotoxicological parameters in order to provide information for the public management and conservation of aquatic environments. In this context, this pioneering research aimed to investigate the water quality of the Poxim River estuary throughout the dry and rainy seasons.

\section{MATERIALS AND METHODS}

The Poxim River drainage sub-basin covers an area of approximately $400 \mathrm{~km}^{2}$ and is composed of the Poxim-Açu, Poxim-Mirim and Pitanga rivers (Aguiar Netto et al. 2013). The Poxim River extends about $45 \mathrm{~km}$ (between latitudes $10^{\circ} 55^{\prime} \mathrm{S}$ and $10^{\circ} 45^{\prime} \mathrm{S}$, and longitudes $37^{\circ} 05^{\prime} \mathrm{W}$ and $37^{\circ} 22^{\prime}$ W) from the main spring located in the Serra dos Cajueiros in Itaporanga d'Ajuda until reaching its confluence with the Sergipe River near the Atlantic Ocean (Fig. 1). This region presents typical climate characteristics of the Brazilian northeast with tropical weather divided into the dry season (August to March) and rainy season (April to July); the temperature varies between $23{ }^{\circ} \mathrm{C}$ and $31{ }^{\circ} \mathrm{C}$ 
(INMET 2016). The Poxim estuary is located in the densely populated urban area of Aracaju $\left(3,140.65\right.$ inhabitants $\left./ \mathrm{Km}^{2}\right)$ (IBGE 2010) and has an approximate extension of $9 \mathrm{~km}$, a maximum width of $100 \mathrm{~m}$, and an average depth of $2 \mathrm{~m}$.

Water samples were collected bimonthly between August 2014 and July 2015 at three sampling stations: E1 (1057'25.01”S $37^{\circ}$ 4'9.37”W), the Ponte Gilberto Vila Nova de Carvalho, Inácio Barbosa; E2 (1057’33.09’’S $37^{\circ}$ 3'13.95"W), the Parque dos Cajueiros, Farolândia; and E3 (1056'30.89's 37 2'58.01'W), Ponte Godofredo Diniz, 13 de Julho. Stations E1 and E2 were separated by a distance of $1.2 \mathrm{~km}$, and stations E2 and E3 were separated by a distance of $2.2 \mathrm{~km}$. These sites were chosen due to ease of access for sampling, which was done from the top of bridges and piers. Situated on the right side in the direction of the river mouth, Stations 1 and 2 lie within two municipal parks (the Parque Natural do Rio Poxim and the Parque dos Cajueiros); however, they are marked by the intense human occupation and include residences and commercial buildings.
Station 3 is near a shopping center and faces a channel mouth that drains effluent and rainwater and dampens high tides.

Surface water samples were collected using ropes and ballasts and stored in 1-L polyethylene flasks that were rinsed with $10 \%$ nitric acid and distilled water. Dissolved oxygen (D.O.), $\mathrm{pH}$, temperature, and salinity were measured in situ by means of oximeter with thermometer, $\mathrm{pH}$ meter and refractometer, respectively. Water samples were always collected during low tide and the sample flasks were kept in a thermal box until arrival at the laboratory (about $2 \mathrm{~h}$ later).

The $M$. juniae specimens were provided by the Ecotoxicological Studies Laboratory (LESE) at the Federal University of Sergipe, and both the organism maintenance and acute toxicity tests (96 h) followed NBR 15.308 (ABNT 2011). The health of the organisms was monitored with zinc as a reference substance $\left(\mathrm{ZnSO}_{4} \cdot 7 \mathrm{H}_{2} \mathrm{O}\right)$ prepared in artificial seawater, with plain seawater used as a control. Seawater (salinity: 35) was produced by dissolving commercial sea salt (Red Sea) in

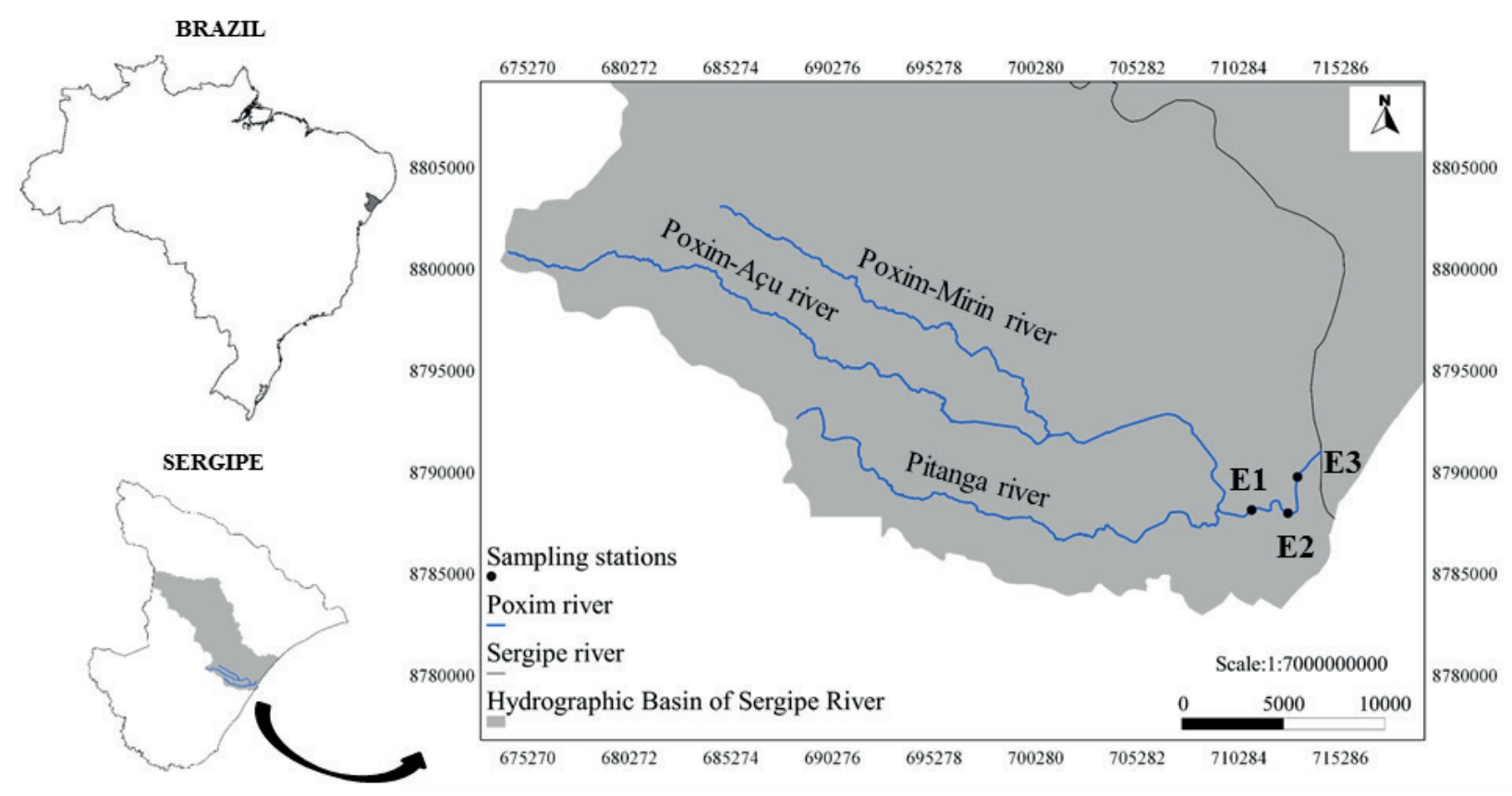

Figure 1 - Study area showing the sampling stations in the Poxim River, Sergipe, Brazil. 
distilled water. Commercial sea salt was also used to correct the salinity of the river samples with values lower than 35 .

Water samples were stored in a freezer for seven to fifteen days prior the test, slowly thawed in a refrigerator 24 hours prior to assays, and acclimated to room temperature $\left(25 \pm 2{ }^{\circ} \mathrm{C}\right)$ on the experimental days. After thawing, the physical and chemical parameters were re-measured (salinity, $\mathrm{pH}$, D.O., temperature), and total/toxic ammonia and nitrite were assessed using a colorimetric kit (Alcon Labcon test). Organism exposure to the environmental samples and the reference substance followed the same procedures (ABNT 2011). One to seven-day-old juvenile $M$. juniae were exposed to either the water samples or the reference substance continuously for $96 \mathrm{~h}$ without aeration in a controlled environment with a 12 $\mathrm{h}: 12 \mathrm{~h}$ photoperiod and a temperature of $25 \pm 2{ }^{\circ} \mathrm{C}$. Ten juveniles were added to each $300 \mathrm{ml}$ beaker (in triplicate) and fed daily with Artemia sp. (48 h). The physiochemical parameters were measured again at the end of the experiment.

M. juniae mortality (i.e., the number of dead individuals) at the end of exposure period for the reference substance was used to calculate the median lethal concentration (LC50) using the Trimmed Spearman-Karber method (Hamilton et al. 1977). Normal distribution with logarithm transformed data was analyzed with the ShapiroWilk's test, and then one-way analysis of variance (ANOVA) followed by a Dunnett's test was used to evaluate the survival of mysids after exposure to water samples from the Poxim river estuary using GraphPadPrism version 5.01.

\section{RESULTS AND DISCUSSION}

Current legislation characterizes the study area as brackish, which indicates a salinity range between 0.5 and 30 (CONAMA 2005). However, this water body has not been properly classified by the responsible environmental agency and is generally considered as Class 2, which means that it is reserved for amateur fishing and recreation and is excluded for use in the protection of aquatic communities, aquaculture and fishing activities. Schneider et al. (2016), after four years of monitoring this area, concluded that the estuarine region (located near E2) has physiochemical and microbiological characteristics that are non-compliant for this class and concluded that the water characteristics more closely match the more severe classification (Class 3), indicative of water to be used only for navigation and landscape harmony.

The variation in salinity was within the range expected for the region with values increasing from E1 to E3 (Table I). The lowest salinity values were observed in July, which is expected considering the increase of the river flow rate due to the rainy season (April to July). It is important to point out that pluviosity in 2015 was more intense $(690 \mathrm{~mm})$ than the previous year $(280 \mathrm{~mm})$ (INMET 2016), and this could alter substances distribution, transport and bioavailability. The water temperature varied within the expected range for the region with an average of $30.3 \pm 1.3{ }^{\circ} \mathrm{C}$. The $\mathrm{pH}$ of the Poxim River was in compliance with the legislation for Class 2 at all stations surveyed (CONAMA 2005).

Dissolved oxygen was the parameter that showed the greatest seasonal differences, especially in the months of April and July (rainy season), when values were below those expected for Class 3 $\left(>3 \mathrm{mg} \mathrm{L}^{-1}\right)$ at stations E1 and E2, and for Class 2 ( $>4 \mathrm{mg} \mathrm{L}^{-1}$ ) for station E1 (in April) (Table I). These results agree with those of other studies showing that values below $2 \mathrm{mg} \mathrm{L}^{-1}$ were associated with release of domestic and industrial effluents. This has contributed to critical pollution levels in the Poxim River in recent decades, not only in the estuarine region but also in the freshwater portions, including the catchment containing water for human consumption (Aguiar Netto et al. 2013, Vasco et al. 2011). 
TABLE I

Physiochemical parameters of in situ water samples from the Poxim River estuary in Sergipe (E1 - Inácio Barbosa; E2 Parque dos Cajueiros; E3 - 13 de julho) from August 2014 to July 2015.

\begin{tabular}{|c|c|c|c|c|c|c|c|c|c|}
\hline \multirow[b]{2}{*}{ Parameters } & \multirow[b]{2}{*}{ Stations } & \multirow[b]{2}{*}{ Aug14 } & \multirow[b]{2}{*}{ Oct14 } & \multirow[b]{2}{*}{ Dec14 } & \multirow[b]{2}{*}{ Feb15 } & \multirow[b]{2}{*}{ Apr15 } & \multirow[b]{2}{*}{ Jul15 } & \multicolumn{2}{|c|}{ Reference values ${ }^{\mathrm{a}}$} \\
\hline & & & & & & & & Class 2 & Class 3 \\
\hline D.O. & E1 & 7.35 & 7.15 & 9.78 & 6.51 & 2.21 & 1.41 & & \\
\hline \multirow[t]{3}{*}{$\left(\mathrm{mg} \mathrm{L}^{-1}\right)$} & E2 & 7.15 & 7.40 & 8.23 & 6.10 & 2.81 & 1.58 & $>4.0$ & $>3.0$ \\
\hline & E3 & 7.65 & 7.83 & 8.42 & 6.34 & 3.20 & 4.51 & & \\
\hline & E1 & 7.6 & 7.8 & 7.0 & 7.0 & 6.9 & 7.0 & & \\
\hline \multirow[t]{3}{*}{ pH } & E2 & 7.4 & 7.4 & 8.0 & 8.0 & 7.1 & 7.0 & 6.5 to 8.5 & 5 to 9 \\
\hline & E3 & 7.1 & 7.1 & 8.0 & 8.0 & 7.4 & 8.0 & & \\
\hline & E1 & 5 & 5 & 7 & 10 & 0 & 5 & & \\
\hline \multirow[t]{2}{*}{ Salinity } & E2 & 16 & 15 & 18 & 20 & 5 & 5 & & \\
\hline & E3 & 18 & 32 & 30 & 35 & 25 & 13 & & \\
\hline Temperature & E1 & 29.9 & 30.4 & 31.3 & 31.1 & 31.5 & 28.1 & & \\
\hline \multirow[t]{2}{*}{$\left({ }^{\circ} \mathrm{C}\right)$} & E2 & 29.8 & 29.2 & 32.8 & 31.7 & 30.1 & 28.3 & & \\
\hline & E3 & 30.0 & 29.5 & 30.4 & 32.3 & 29.7 & 29.1 & & \\
\hline
\end{tabular}

${ }^{\mathrm{a}}$ According to Brazilian legislation for water quality (CONAMA 2005).

The freezing process altered the physiochemical characteristics of the samples; thus, the parameters (salinity, pH, D.O., temperature) were measured again prior to the ecotoxicological assays to verify the minimum conditions for mysid survival. The physiochemical parameters were measured at the beginning and end of each experiment (including controls), and were within the acceptable range for the assays (ABNT 2011). The mean $\mathrm{pH}$ was $8.0 \pm 0.3$ $(\mathrm{CV}=3.12 \%, \mathrm{n}=40)$, the mean D.O. concentration was $6.6 \pm 0.6 \mathrm{mg} \mathrm{L}^{-1}(\mathrm{CV}=9.09 \%, \mathrm{n}=40)$, the mean temperature was $25.2 \pm 0.5{ }^{\circ} \mathrm{C}(\mathrm{CV}=1.83 \% \mathrm{n}=40)$, and mean salinity (corrected before freezing) was $34.8 \pm 0.6(\mathrm{CV}=1.86 \%, \mathrm{n}=40)$.

Ammoniacal nitrogen $\left(\mathrm{NH}^{+}+\mathrm{NH} 3\right)$ and non-ionized ammonia $\left(\mathrm{NH}_{3}\right)$ levels, measured after thawing of samples, were highest at stations E1 and E2, independent of sampling time (Table II). This supports the hypothesis that domestic effluents in the inland portion of the estuary contribute to water degradation. The values were above those recommended in the CONAMA resolution $357 / 2005$, in which the maximum values allowed for brackish waters are $0.40 \mathrm{mg} \mathrm{L}^{-1}$ (class 1) and $0.70 \mathrm{mg} \mathrm{L}^{-1}$ (class 2), in all months with the exception of E3 in October 2014 and April 2015. The high levels of nitrogen in the Poxim River are associated with agricultural activity and effluent discharge and concentrations increase as the river permeates the urban zone, mainly in the estuarine region (Alves et al. 2007, Vasco et al. 2011). High levels of ammoniacal nitrogen are indicative of recent effluent release, and depending on biotic and abiotic environmental conditions, organic nitrogen may be converted into non-ionized ammonia $\left(\mathrm{NH}_{3}\right)$, which is highly toxic to aquatic animals. Untreated and wastewater-treated domestic sewage carries several types of substances, namely cationic surfactants as quaternary ammonium compounds that can persist in receiving waters after sorption by sediment particles, which essentially serve as a reservoir for these pollutants ( $\mathrm{Li}$ and Brownawell 2010).

Assays evaluating the sensitivity of $M$. juniae to the reference substance resulted in an $\mathrm{LC}_{50}$ of $0.35 \pm 0.04 \mathrm{mg} \mathrm{L}^{-1}$, which is in accordance with 
values reported in the literature (Badaró Pedroso et al. 2002, Figueredo et al. 2015) and shows that the mysids were healthy and sufficiently sensitive for assessment of the Poxim River water quality.

Exposure to water samples from the E1 and E2 stations of the Poxim River estuary in August 2014 and February 2015 resulted in acute toxicity for mysids, as did exposure to water from December 2014 in all stations (Fig. 2). According to the CONAMA resolution $n^{\circ} 357$, brackish water in Class 2 should not present acute toxicity. However, our data clearly show acute effects, demonstrating that water quality in the Poxim estuary is lower than it should be for Class 2 categorization. There were no significant differences in the physiochemical parameters of water samples from station E1, which suggests that high pollution levels are more or less constant in this station area. Although there was no significant difference in mysid survival, in October and July there was reduction to $53.3 \pm$ $28.8 \%$ and $56.5 \pm 11.6 \%$, respectively, compared to the controls. The stations with lower salinity values (in situ) had the lowest mysid survival rates, indicating that the agents causing pollution in the estuary enter through the river. In addition to domestic effluents, the river receives industrial effluents (e.g., food, textile, plastic, ceramics, and metallurgic) associated with the presence of metals in the sediment in low concentrations (e.g., $\mathrm{Cu}$, $\mathrm{Ni}, \mathrm{Pb}$ and $\mathrm{Zn}$ ) (Alves et al. 2007, Garcia et al. 2009). Recently, it was recorded a presence of 16 priority polycyclic aromatic hydrocarbons (PAH) along the estuary (Souza et al. 2018), mainly 5-6 rings compounds that are more toxic (benzo(b) fluoranthene, benzo(g,h,i)perylene, indeno(1,2,3$\mathrm{c}, \mathrm{d})$ pyrene and benzo(a)pyrene), and also 4 rings compounds (fluoranthene and pyrene), including in the same sites researched in this present study. These findings were associated to a pyrogenic origin like as a fossil fuel combustion (vehicle traffic and biomass burn), and although the PAH concentrations were below the threshold effect level
(TEL) for single substance toxicity, determined by Buchman et al. (2008), it is important to consider that compounds mixtures can be more toxic than single exposures (Engraff et al. 2011).

Oxygen concentrations were lower in the rainy months, but this did not negatively affect the mysids due to changes in D.O. during the salinization and freezing processes. It is, however, possible that the substances contributing to water toxicity are diluted by rain (Vasco et al. 2011). The first flushing from the rainy season tends to transport large amounts of nitrogen compounds from urban rivers into the direction of the coastal areas, and results in ammonia storage in the sediment during the dry season (Rosenzweig et al. 2008). The contribution of rainfall to contaminant dilution or increased runoff seems to be dependent on the sources of pollution (Kayhanian et al. 2008). In another urban estuary located in the northeast (state of Ceará), diffuse sources contribute to the increase in chronic water toxicity, mainly in the rainy season due to surface runoff (Nilin et al. 2007). Instead, the point sources in the Poxim river estuary are strongly concentrated around the margins. These effluents contribute to increased toxicity due to decomposing organic load especially in the dry season, as do other domestic products such as surfactants, pharmaceuticals, and personal care products. We highlight that tropical and semi-arid regions such as the Poxim river subbasin suffer long droughts, and the water resources are becoming less abundant, which can worsen the quality of urban rivers in combination with the environmental pressure caused by the increasing human population, including flow manipulation for catchment (Nilsson and Renöfält 2008).

Ecotoxicological studies of estuarine areas are still scarce in the Brazilian northeast (Buruaem et al. 2013, Nilin et al. 2013, Oliveira et al. 2014), and most of them evaluate sediment quality. In this study, the acute toxicity test using $M$. juniae was found to be appropriate for evaluation of water quality in an urban estuary. Mysids are used worldwide to 
TABLE II

Ammoniacal nitrogen and non-ionized ammonia of water samples (after thawing) from the Poxim River estuary - Sergipe (E1 - Inácio Barbosa; E2 - Parque dos Cajueiros; E3 - 13 de julho), from August 2014 to July 2015.

\begin{tabular}{ccccccccc}
\hline & & & & & & & & Reference Values $^{\mathrm{a}}$ \\
\hline Parameters & Stations & Aug14 & Oct14 & Dec14 & Feb15 & Apr15 & Jul15 & \\
\hline Ammoniacal nitrogen & Control & 0.25 & 0.25 & 0.25 & 0.25 & 0 & 0.25 & \\
$\left(\mathrm{mg} \mathrm{L}^{-1}\right)$ & E1 & 3.00 & 3.00 & 3.00 & 3.00 & 3.00 & 1.50 & $<0.40$ Class 1 \\
& E2 & 1.50 & 3.00 & 1.50 & 3.00 & 3.00 & 3.00 & $<0.70$ Class 2 \\
& E3 & 1.00 & 0.25 & 1.00 & 3.00 & 0.50 & 1.50 & \\
Non-ionized ammonia & Control & 0.009 & 0.014 & 0.014 & 0.0 & 0.0 & 0.009 & \\
$\left(m g L^{-1}\right)$ & E1 & 0.557 & 0.164 & 0.164 & 0.164 & 0.034 & 0.557 & \\
& E2 & 0.230 & - & 0.168 & 0.164 & 0.067 & 0.557 & \\
& E3 & 0.127 & 0.055 & 0.108 & 0.018 & 0.034 & 0.009 & \\
\hline
\end{tabular}

${ }^{a}$ According to the Brazilian legislation for water quality (CONAMA 2005).
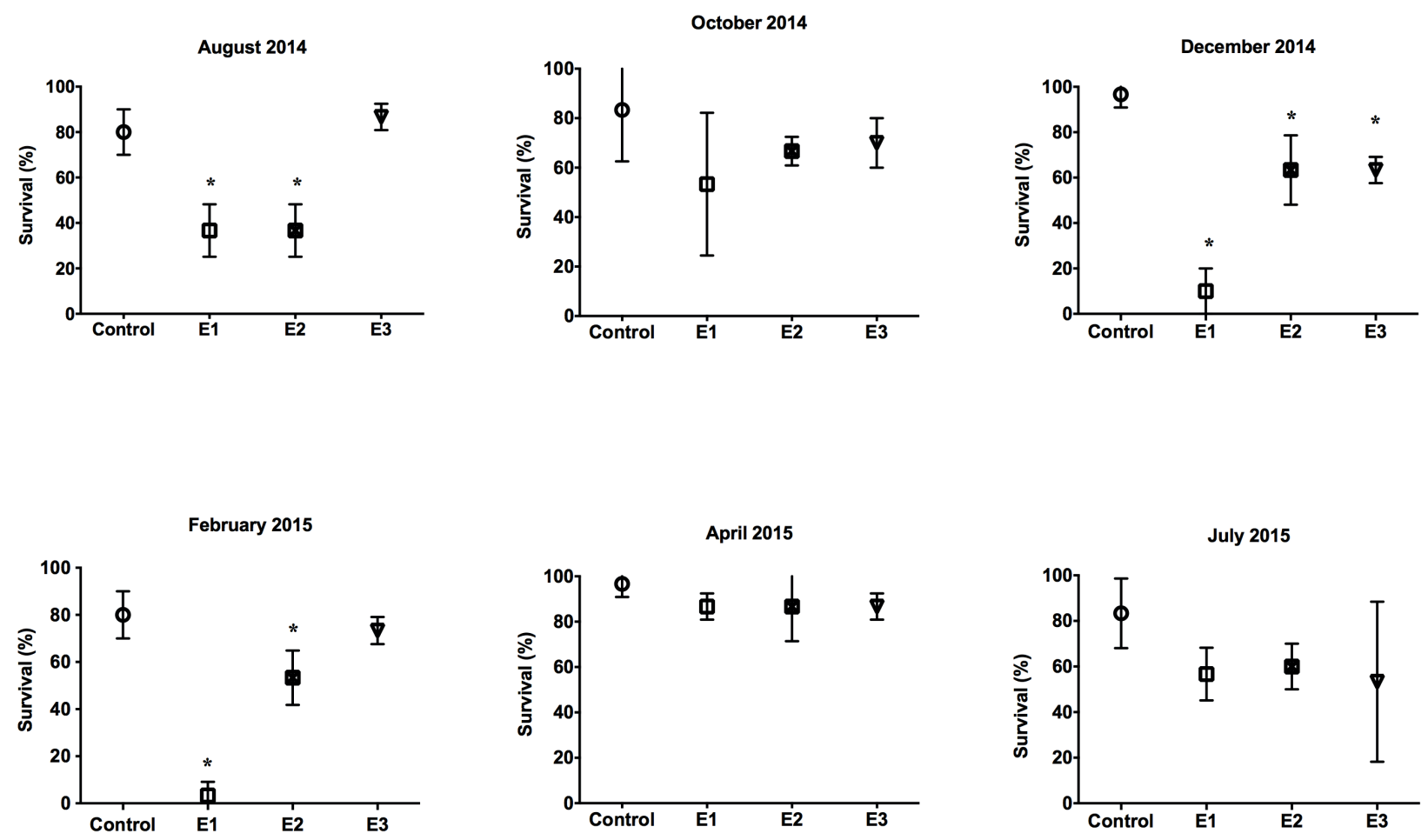

Figure 2 - Survival of Mysidopsis juniae 96 hours after exposure to water samples from the Poxim River estuary in Aracaju, Sergipe (E1 - Inácio Barbosa; E2 - Parque dos Cajueiros, E3 - July 13). *ANOVA followed by Dunnett's test (p $\leq 0.05)$ 
monitor estuarine and marine water quality, as well as to determine the levels of a variety of substances that can impair water quality such as crude oil and dispersants (Echols et al. 2015, Hemmer et al. 2011), pesticides (DeLorenzo et al. 2014, Noppe et al 2007, Perez et al. 2015); surfactants (Hirano et al. 2009) and metals (Burgess et al. 2007, Erk et al. 2008). Beyond the acute effects that can affect the food chain structure by decreasing a specific population or an entire community, this group has been highlighted as a useful model for the assessment of chronic effects (e.g., growth, weight, fecundity, and other factors used as biomarkers), mainly for $M$. juniae (Figueiredo et al. 2016, Gurgel et al. 2016, US.EPA 2002, Vaz et al. 2013, Verslycke et al. 2007). This reinforces the relevance of the use of representative and sensitive zooplankton for monitoring urban estuaries that receives a complex mixture of compounds, including micropollutants such as pharmaceuticals, personal care products, hormones, surfactants and domestic pesticides. These biological effects should be promptly included in monitoring practices for north-eastern water bodies, which, combined with physiochemical assays, can help to better describe and evaluate the associated environmental impacts (Martins and Bianchini 2011).

Our results from the ecotoxicological assay of the estuarine waters of the Poxim River showed that the pollutants contributing to the degradation of environmental quality in this important water resource are transported from the basin to the mouth. Significant acute toxic effects were found, especially for water collected during the dry season, that reinforce Schneider et al. (2016) statements about Poxim river quality non-compliance with legislation. Undoubtedly, domestic and industrial urban effluents are the main cause of the observed deterioration. Given this situation, we must adopt active measures to support environmental restoration for the maintenance of biodiversity, ecological functions and ecosystems services, and public policies must be established to control and treat effluents in water bodies while considering the effects of climate change on water management and mangrove conservation (Lee et al. 2014, Nilsson and Renöfält 2008).

\section{ACKNOWLEDGMENTS}

The authors are grateful to José Bruno Melo Alves, Josivânia Souza and Walkiria Honorato for the help with sampling and culture of mysids. We also thank Conselho Nacional de Desenvolvimento Científico e Tecnológico (CNPq) (process n ${ }^{\circ} 484923 / 2013-7$ ) for financial support for the implantation of mysid cultures and Coordenação de Aperfeiçoamento de Pessoal de Nível Superior (CAPES) for a Master's research grant to MKSN and language revision (PROEF 88881.157451/2017-01).

\section{REFERENCES}

ABNT - ASSOCIAÇÃO BRASILEIRA DE NORMAS TÉCNICAS. 2011. NBR15308: Ecotoxicologia aquática - Toxicidade aguda - Método de ensaio com misidáceos (Crustacea). Associação Brasileira de Normas Técnicas, $20 \mathrm{p}$.

AGUIAR NETTO AO, FERREIRA RA, ALVES JPH, GARCIA CAB, COSTA AM, MOREIRA FD, MACEDO LD AND NASCIMENTO NS. 2013. Cenário dos corpos d'água na sub-bacia hidrográfica do rio Poxim - Sergipe, na zona urbana, e suas relações ambientais e antrópicas. In: XVII Simpósio Brasileiro de Recursos Hídricos. São Paulo, Brasil, p. 1-19.

ALVES JDPH, PASSOS EDA AND GARCIA CAB. 2007. Metals and acid volatile sulfide in sediment cores from the Sergipe River Estuary, Northeast, Brazil. J Braz Chem Soc 18: 748-758.

ARAUJO HMP, NASCIMENTO-VIEIRA DA, NEUMANNLEITÃO S, SCHWAMBORN R, LUCAS APO AND ALVES JPH. 2008. Zooplankton community dynamics in relation to the seasonal cycle and nutrient inputs in an urban tropical estuary in Brazil. Braz J Biol 68(4): 751762.

BADARÓ-PEDROSO C, REYNIER MV AND PRÓSPERI VA. 2002. Testes de toxicidade aguda em misidáceos ênfase nas espécies Mysidopsis juniae e Mysidium gracile (Crustacea: Mysidacea). In: Nascimento IA, Sousa ECPM, Nipper M (Eds), Métodos de ecotoxicologia marinha. Aplicações no Brasil. Artes Gráficas e Indústria Ltda, p. 123-139. 
BRASIL. 1997. Lei nº 9.433 de 08 de janeiro de 1997. PR, Brasília, Brasil. Disponível em: http://www.planalto.gov. br/ccivil 03/LEIS/L9433.htm (Acesso em 17 Out. 2018).

BRITTO FB, DO VASCO AN, PEREIRA APS, MÉLLO AV AND NOGUEIRA LC. 2012. Herbicidas no alto Rio Poxim, Sergipe e os riscos de contaminação dos recursos hídricos. Rev Cienc Agron 43(2): 390-398.

BUCHMAN MF. 2008. NOAA Screening Quick Reference Tables, NOAA OR\&R Report 08-1 Seattle WA. Office of Response and Restoration Division, National Oceanic and Atmospheric Administration, 34 p. Available at: https:// response.restoration.noaa.gov/sites/default/files/SQuiRTs. pdf (Accessed on December 22, 2017).

BURGESS R M, PERRON MM, CANTWELL MG, HO KT, PELLETIER MC, SERBST JR AND RYBA AS. 2007. Marine sediment toxicity identification evaluation methods for the anionic metals arsenic and chromium. Environ Toxicol Chem. 26: 61-67.

BURUAEM LM, ARAUJO GS, ROSA PA, NICODEMO SC, PORTO VF, FONSECA JR, CRUZ JV, MEDEIROS GF AND ABESSA DMS. 2013. Assessment of sediment toxicity from the Areia Branca off-shore harbor and the Potengi river estuary ( $\mathrm{RN})$, northeastern Brazil. Panam J Aquat Sci 8: 312-326.

CONAMA - CONSELHO NACIONAL DO MEIO AMBIENTE. 2005. Resolução n 357 de 18 de março de 2005. Brasília, Brasil. Disponível em: http:/www2.mma. gov.br/port/conama/legiabre.cfm?codlegi $=459$ (Acesso em 17 Out. 2018).

DE AGUIAR NETTO AO, GARCIA CAB, HORA ALVES JDP, FERREIRA RA AND DA SILVA MG. 2013. Physical and chemical characteristics of water from the hydrographic basin of the Poxim River, Sergipe State, Brazil. Environ Monit Assess 185(5): 4417-4426.

DELORENZO ME, KEY PB, CHUNG KW, SAPOZHNIKOVA Y AND FULTON MH. 2014. Comparative toxicity of pyrethroid insecticides to two estuarine crustacean species, Americamysis bahia and Palaemonetes pugio. Environ Toxicol 29: 1099-1106.

ECHOLS BS, SMITH AJ, GARDINALI PR AND RAND GM. 2015. Acute aquatic toxicity studies of Gulf of Mexico water samples collected following the Deepwater Horizon incident (May 12, 2010 to December 11, 2010). Chemosphere 120: 131-137.

ENGRAFF M, SOLERE C, SMITH KEC, MAYER P AND DAHLLÖF I. 2011. Aquatic toxicity of PAHs and PAH mixtures at saturation to benthic amphipods: Linking toxic effects to chemical activity. Aqua Toxicol 102(3-4): 142149.

ERK M, MUYSSEN BTA, GHEKIERE A AND JANSSEN CR. 2008. Metallothionein and cellular energy allocation in the estuarine mysid shrimp Neomysis integer exposed to cadmium at different salinities. Exp Mar Bio Ecol 357(2): 172-180.
FERREIRA AC AND LACERDA LD. 2016. Degradation and conservation of Brazilian mangroves, status and perspectives. Ocean Coast Manag 125: 38-46.

FIGUEREDO LP, NILIN J, SILVA AQ, DAMASCENO EP, LOUREIRO S AND COSTA-LOTUFO LV. 2015. Zinc and nickel binary mixtures act additively on the tropical mysid Mysidopsis juniae. Mar Freshw Res 67(3): 301-308.

FIGUEREDO LP, NILIN J, SILVA AQ, LOUREIRO S AND COSTA-LOTUFO LV. 2016. Development of a short-term chronic toxicity test with a tropical mysid. Mar Poll Bull 106(1): 104-108.

GARCIA CAB, BARRETO MS, PASSOS EA AND ALVES JDPH. 2009. Regional geochemical baselines and controlling factors for trace metals in sediments from the Poxim river, Northeast Brazil. J Braz Chem Soc 20(7): 1334-1342.

GURGEL PM, NAVONI JA, FERREIRA DM AND AMARAL VS. 2016. Ecotoxicological water assessment of an estuarine river from the Brazilian Northeast, potentially affected by industrial wastewater discharge. Sci Total Environ 572: 324-332.

HAMILTON MA, RUSSO RC AND THURSTON RV. 1977. Trimmed Spearman-Karber method for estimating median lethal concentrations in toxicity bioassays. Environ Sci Technol 11(7): 714-719.

HATJE V, DE SOUZA MM, RIBEIRO LF, EÇA GF AND BARROS F. 2016. Detection of environmental impacts of shrimp farming through multiple lines of evidence. Environ Pollut 219: 672-684.

HEMMER MJ, BARRON MG AND GREENE R M. 2011. Comparative toxicity of eight oil dispersants, Louisiana sweet crude oil (LSC), and chemically dispersed LSC to two aquatic test species. Environ Toxicol Chem 30: 22442252.

HIRANO M, ISHIBASHI H, KIM JW, MATSUMURA N AND ARIZONO K. 2009. Effects of environmentally relevant concentrations of nonylphenol on growth and 20-hydroxyecdysone levels in mysid crustacean, Americamysis bahia. Comp Biochem Physiol C Pharmacol Toxicol 149(3): 368-373.

IBGE - INSTITUTO BRASILEIRO DE GEOGRAFIA E ESTATÍSTICA. 2010. Pesquisa Nacional de Saneamento Básico. IBGE, Rio de Janeiro, Brasil. Disponível em: https://www.ibge.gov.br/estatisticas-novoportal/ multidominio/meio-ambiente/9073-pesquisa-nacionalde-saneamento-basico.html? $=\& \mathrm{t}=\mathrm{o}-$ que-e $($ Acesso em 17 Out. 2018).

INMET - INSTITUTO NACIONAL DE METEOROLOGIA. 2016. Gerador de gráficos. INMET, Brasil. Disponível em: http://www.inmet.gov.br/portal/index.php?r=tempo/ graficos. (Acesso em 17 Out. 2018).

KAYHANIAN M, STRANSKY C, BAY S, LAU L AND STENSTROM MK. 2008. Toxicity of urban highway 
runoff with respect to storm duration. Sci Total Environ 389: 386-406.

LEE SY ET AL. 2014. Ecological role and services of tropical mangrove ecosystems: a reassessment. Glob Ecol Biogeogr 23: 726-743.

LI XAND BROWNAWELL BJ. 2010. Quaternary Ammonium Compounds in Urban Estuarine Sediment Environments A Class of Contaminants in Need of Increased Attention? Environ Sci Technol 44(19): 7561-7568.

MACIEL DC, DE SOUZA JRB, TANIGUCHI S, BÍCEGO MC AND ZANARDI-LAMARDO E. 2015. Sources and distribution of polycyclic aromatic hydrocarbons in an urbanized tropical estuary and adjacent shelf, Northeast of Brazil. Mar Pollut Bull 101(1): 429-433.

MARTINS SE AND BIANCHINI A. 2011. Toxicity tests aiming to protect Brazilian aquatic systems: current status and implications for management. J Environ Monit 13(7): 1866-1875.

NGUYEN HH, MCALPINE C, PULLAR D, JOHANSEN K AND DUKE NC. 2013. The relationship of spatialtemporal changes in fringe mangrove extent and adjacent land-use: Case study of Kien Giang coast, Vietnam. Ocean Coast Manag 76: 12-22.

NILIN J, CASTRO CB, PIMENTEL M, FRANKLIN JR W, MATOS RFG, LOTUFO TMZ AND COSTA-LOTUFO L. 2007. Water toxicity assessment of the Ceará river estuary (Brazil). J Braz Soc Ecotoxicol 2: 107-113.

NILIN J, MOREIRA LB, AGUIAR JE, MARINS R, ABESSA DMS, LOTUFO TMC AND COSTA-LOTUFO LV. 2013. Sediment quality assessment in a tropical estuary: The case of Ceará River, Northeastern Brazil. Mar Environ Res 91: 89-96.

NILSSON C AND RENÖFÄLT BM. 2008. Linking flow regime and water quality in rivers: a challenge to adaptive catchment management. Ecol Soc 13(2): 18.

NOPPE H, GHEKIERE A, VERSLYCKE T, WULF ED, VERHEYDEN K, MONTEYNE E, POLFLIET K, CAETER P, JANSSEN CR AND BRABANDER HF. 2007. Distribution and ecotoxicity of chlorotriazines in the Scheldt Estuary (B-Nl), Environ Poll 147(3): 668-676.

OECD - ORGANISATION FOR ECONOMIC COOPERATION AND DEVELOPMENT. 2006. Detailed review paper on aquatic arthropods in life cycle toxicity tests with an emphasis on developmental, reproductive and endocrine disruptive effects.

OECD 55: 125. OLIVEIRA DD, SOUZA-SANTOS LP, SILVA HKP AND MACEDO SJ. 2014. Toxicity of sediments from a mangrove forest patch in an urban area in Pernambuco (Brazil). Ecotoxicol Environ Saf 104: 373378.

PÉREZ S, RIAL D AND BEIRAS R. 2015. Acute toxicity of selected organic pollutants to saltwater (mysid Siriella armata) and freshwater (cladoceran Daphnia magna) ecotoxicological models Ecotoxicology 24: 1229-1238.
SCHNEIDER EHM, MENDONÇA LC AND MENDES LA. 2016. Avaliação da qualidade das águas do Rio Poxim em Aracaju quanto à balneabilidade e ao enquadramento. XIII Simpósio de Recursos Hídricos do Nordeste, Sergipe, Brasil, p. 1-4.

SILVA AS, BUSCHINELLI CCA, RODRIGUES IA AND MACHADO RE. 2004. Índice de sustentabilidade ambiental do uso da água (ISA ÁGUA): municípios da região do entorno do rio Poxim, SE. Embrapa Meio Ambiente, Jaguariúna, Brazil, 46 p.

SILVA VMAP. 1979. Mysidopsis juniae, nova espécie de Crustacea-Mysidacea. Departamento de Zoologia, Instituto de Biologia do Centro de Ciências da Saúde, Universidade Federal do Rio de Janeiro 30, p. 1-4.

SOUZA MRR, SANTOS E, SUZARTE JS, CARMO LO, FRENA M, DAMASCENO FC AND ALEXANDRE MR. 2018. Concentration, distribution and source apportionment of polycyclic aromatic hydrocarbons $(\mathrm{PAH})$ in Poxim River sediments, Brazil. Mar Poll Bull 127: 478-483.

SUÁREZ-ABELENDA M, FERREIRA TO, CAMPSARBESTAIN M, RIVERA-MONROY VH, MACÍAS F, NÓBREGA GN AND OTERO XL. 2014. The effect of nutrient-rich effluents from shrimp farming on mangrove soil carbon storage and geochemistry under semi-arid climate conditions in northern Brazil. Geoderma 213: 551559.

ROSENZWEIG BR, MOON HS, SMITH JA, BAECK ML AND JAFFE PR. 2008. Variation in the instream dissolved inorganic nitrogen response between and within rainstorm events in an urban watershed. J Environ Sci Health A Tox Hazard Subst Environ Eng 43(11): 1223-1233.

US.EPA. 2002. Methods for Measuring the Acute Toxicity of Effluents and Receiving Waters to Freshwater and Marine Organisms. United States Environmental Protection Agency, Office of Water, Washington, D.C EPA821-R-02-014, $486 \mathrm{p}$.

VASCO AN, BRITTO FB, PEREIRA APS, MÉLLO JÚNIOR AVM, GARCIA CAB AND NOGUEIRA LC. 2011. Avaliação espacial e temporal da qualidade da água na sub-bacia do rio Poxim, Sergipe, Brasil. Ambi-Agua 6(1): 118-130.

VAZ C, KLEINE T, TORTELLI TS, BOHM RFS, SPITZNER EC, GONCALVES RA, BARROS VG, SIMM M, DE OLIVEIRA TMN AND MATIAS WG. 2013. Assessment of chronic toxicity in water samples from the Babitonga bay - south of Brazil - using transgenerational testing with Mysidopsis juniae. Fresen Environ Bull 22(7): 1967-1976.

VERSLYCKE T, GHEKIERE A, RAIMONDO S AND JANSSEN C. 2007. Mysid crustaceans as standard models for the screening and testing of endocrine-disrupting chemicals. Ecotoxicology 16: 205-219. 